Mavi Atlas, 5(2)/2017: 474-488.

Araştırma Makalesi | Research Article

Makale Geliş | Received: 20.08.2017

Makale Kabul | Accepted: 16.09.2017

DOI: 10.18795/gumusmaviatlas.356653

Meriç AYBAR

Yrd. Doç. Dr. | Assist. Prof. Dr. Erzincan Üniversitesi, Fen-Edebiyat Fakültesi, Tarih Bölümü, Erzincan-Türkiye Erzincan University, Faculty of Science and Literature, Department of History, Erzincan-Turkey orcid.org/0000-0002-6541-6416 maybar@erzincan.edu.tr

\title{
Osmanlı Devletinde Kıtlık ve İç Göç: 1870-1900 Arası İç Anadolu Örneği
}

$\ddot{O} z$

İlk insanlarla başlayan göç olayı günümüze kadar hız kesmeden varlığını hissettirmeye devam etmiştir. Tarihte göç kavramı farklı nedenlerden dolayı ortaya çıkmıştır. Bazen bir yiyecek bulma isteği tıpkı ilk insanlarda olduğu gibi, bazen de yeni yurtlar keşfetme isteği ilk Türk devletlerinde olduğu gibi. Ya da bir deprem, bir salgın, savaş ya da aşırı nüfus artı̧ı beraberinde göçü tetiklemiştir. Her ne sebeple olursa olsun göç faktörü kitleleri yerinden etmiş hem terk edilen yerlerde hem de yeni gidilen yerlerde kalıcı etkiler meydana getirmiştir. Göç olgusu sadece tarihi yönden değil, sosyolojik, psikolojik, coğrafi ya da daha sayılacak birçok alanda incelenmesi gerekmektedir. Bu çalışmada biz bu geniş konu içerisinde Osmanlının 19. yüzyılının sonlarında kıtlıklara bağlı göç olgusunu inceleyeceğiz. Bu çalışmayı yaparken hem arşiv kaynaklarından hem de bilimsel kaynaklardan faydalanacağız.

Anahtar Kelimeler: Osmanlı, Göç, Kıtlık, İç Göç.

\section{The Ottoman Empire Famine and Internal Migration: The Case of Internal Anatolian between 1870-1900}

\begin{abstract}
Starting with the first human migration event presence felt unabated to the present day. The concept of immigration in history have emerged for different reasons. Sometimes a food find request just like as in the first person, sometimes discovering new dormitories, as well as the first Turkish State request. Or an earthquake, epidemic, war or overpopulation triggered migration in together. For whatever reason he and migration factor audiences over abandoned places affects both the new permanent places to be navigated. Migration phenomenon is not only historical way, sociological, psychological, geological examination is required in many areas to count or more. In this study, we in this large Ottoman 19th century will examine the phenomenon of migration connected to famines. While this work and archive sources and scientific sources we use.
\end{abstract}

Keywords: Ottoman, Migration, Famine, Internal Migration. 


\section{Giriş}

Osmanlı Devleti'nin kuruluşundan itibaren göç faktörü kendisini hissettirmiştir. Oğuzların Kayı boyuna mensup olan bu Türkmen Devleti, kurulduğu yere yani Sögüt ve Domaniç dolaylarına gelirken çeşitli göç yollarını geçerek bu bölgeye ulaşmıştır (Gündüz 2012: 14) Osmanlı tarihi boyunca da göç kavramı ile iç içe yaşamıştır. Kuruluş döneminde fethedilen yerlere Anadolu'dan Türkmenler iskân siyasetine bağlı olarak göç ettirilirken (Uzunçarşıllı 1998: 157), bu siyaset sayesinde hem devlet Anadolu'daki konar-göçer grupları yerleşik hale getirmiş hem de fethedilen yerlerde kalıcı olmayı hedeflemiştir.

Osmanlı Devleti’nde göç son dönemlere kadar genellikle kendisini iç göç olarak hissettirmiştir. Bu duruma savaşlar, isyanlar, ekonomik koşullar, vergi şartları ve eğitim gibi faktörler neden olmuştur. Duraklama döneminde Celali isyanları olarak adlandırılan ve taşrada yoğun göçe neden olan bu faktör iç göç olgusuna en güzel örneklerdendir. Sadece bu dönemlerde iç göç tabii ki etkili olmamıştır. Osmanlı Devleti güçlü bir devlet olmasının etkisini zaman zaman ülkeye gelen sığınmacılar ile yoğun bir şekilde hissetmiştir. Bu duruma örnek verecek olursak; kuruluş döneminde Timur tehdidine bağlı olarak Osmanlı'dan yardım isteyen Türkmen boyları Osmanlı'ya sığınmıştır. Ya da gerileme döneminde Rusya tehdidinden kaçan İsveç Kralı Demirbaş Şarl'ın Osmanlıya sığınması ve Rus tehdidinden kaçarak Osmanlı'ya sığınan Macar mültecileri dış göç olgusuna iyi bir örnek olsa gerektir. Osmanlı'nın son dönemi ise felaket yılları olacak, dört koldan saldırılara maruz kalan devlet aynı zamanda bu saldırılar sonucu kaybedilen topraklardan yoğun bir göç akınının yaşanmasına maruz kalacaktır. Aslında devletin kurulduğu coğrafyanın hareketli bir coğrafya olması bu göç olaylarını daha da tetiklemektedir. Aslında bugün Türkiye'nin içinde bulunduğu durumda bu hareketli coğrafyanın bir sonucu olsa gerektir. Osmanlı'nın 19. yüzyılda yaşadığı göçleri sadece toprak kayıplarına bağlamak tabii ki yanlış olacaktır. Depremler, seller, salgınlar, kuraklıklar, kıtlıklar, çekirge felaketleri, aşırı vergi artışları, iç çatışmalar, arazi yetersizlikleri ve eğitim gibi faktörlerde iç göç olgusunun son dönemde fazlası ile 
yaşanmasına zemin hazırlamıştır. Bu çalışmanın sınırları ise kıtlığa bağlı yaşanan göçler ve özellikle İç Anadolu bölgesinde alınan tedbirler oluşturmaktadır.

\section{Kıtlık Kavramı ve İç Göç}

İlk önce kıtlık kavramının tanımını yaparak başlamak istiyorum. Kavram olarak kıtlık ihtiyaç duyulan hayati mamullerin bir şekilde ortadan kalkması ve ulaşılamamasını ihtiva etmektedir. Kıtlık kavramı coğrafi koşulların yanında siyasi ve sosyal nedenlere bağlı olarak da yaşana bilmektedir. Ama bu durumun ana nedeni coğrafi faktörlerdir. Kuraklıklar, aşırı sıcaklık ya da soğukluklar, çekirge istilaları, yangınlar, depremler bu kavramın ortaya çıkışını tetiklemektedir. Ancak bunun yanında savaşlar, isyanlar, eşkıyalık gibi sosyal ve siyasal faktörlerde bu durumun ortaya çıkmasına neden olabilmektedir. Bütün bu nedenlere bakacak olursak bu olayı bir afet olarak tanımlaya biliriz (Gül 2009: 145-158).

Osmanlı Devleti'nde kıtlık olaylarını sadece 19. yüzyıl ile sınırlamak doğru değildir. Daha önceki dönemlerde de bu olaylar sık sık yaşanmıştır. Osmanlı devletinde 16. yüzyıl ve sonrasında görülen bazı kuraklık ve kıtlık olayları şöyle sıralanabilir. 1564 Anadolu'da kıtlık yaşanmış bu nedenle 1565-67 yıllarında Osmanlı Buğday ihracatını yasaklamış, 1586 Çorum'da açlıkla karşılaşıııııs, 1588 İstanbul'da kıtlık, 1660 İstanbul ve Anadolu'da kıtlık görülmüştür (Tekin 2015: 330).

Kitlık olaylarının sadece doğal yollardan olduğu da iddia edilemez. İmparatorluğun kapitülasyonlardan sonra kaderini etkileyen en önemli anlaşma olan Balta Limanı Ticaret Anlaşması İngiltere ve daha sonra hemen hemen benzer maddelerle tüm Avrupa Ülkelerine verilmiştir. Bu anlaşma ile yapılan düzenlemeler beraberinde kıtlığı getirmiştir. Görüldüğü üzere ekonominin kendi iç dinamiklerinden kaynaklanan bir takım olumsuzluklar da kıtlığın sebepleri arasındadır (Oğuz 2016: 530537)

Hicri 1290-1305 (1873-1887) yılları arasında İç Anadolu bölgesinin kıtlıkla boğuştuğu bu dönemdeki yazışmalardan anlaşılmaktadır. İç Anadolu'da özellikle 
Ankara başta olmak üzere Çorum, Kırşehir, Kayseri, Yozgat ve Konya'da bu kıtlıktan olumsuz etkilenmiştir. Bu durum arşiv belgelerinden de açıkça anlaşılmaktadır.

1290 (1873) tarihli Ankara Vilayetine Telgrafname ve Maliye Nezareti Celilesine Tezkire başlıklı telgrafta 1289 (1872) tarihli kıtlık nedeniyle Ankara ahalisinin içinde bulunduğu durum izah edilmekte ve Ankara ahalisine erzak tahsisi hususunda uyarılar yapılmaktadır. Ayrıca maliye nezaretinden bu konuda tedbir alınması istenmektedir (BOA, MKT, MHM 463/81, 1290.)

Kıtlık gerçekten de büyük bir afettir. İnsan aç kaldığında yapmayacağı şey yoktur. İç Anadolu'da meydana gelen bu kıtlık nedeniyle mevcut ambarlar halk tarafından yağmalanmaya başlanmış ve bu durum devleti askeri noktada bazı tedbirler alma yoluna itmiştir. Bu hadiselerin yaşandığı illerden biriside Yozgat ili olmuştur. Yozgat'ta halk açlık nedeniyle ambarlara saldırmaya başlamıştır. Bu konu arşiv belgelerinde de yer almaktadır. 1290 tarihinde Çorum Redif miralaylığına ve Büyük Asker Zabitine yazılan telgrafname suretidir başlıklı yazıda Yozgat'ta zahire azlığından bazı karyelerde ambarların yağmalanmaya başladığı haberlerinin geldiğini ve buna tedbir olarak Çorum'daki neferat-1 ihtiyatiyeden bir bölük piyadenin gönderilmesi için Seraskerlikten Çorum Redif Miralaylığına mezuniyet verilmesi istenmektedir (BOA, MKT, MHM 466/62, 1290). Aynı yazının bir nevi devamı niteliğinde olan bir başka yazıda da; Ankara Vilayet-i Celilesine başlıklı telgrafname de Ankara'da meydana gelen kıtlık ve pahalılık nedeniyle alınan tedabirin sert bir şekilde uygulanmaya devam edilmesi, ayrıca Yozgat'ta meydana gelen yağma hadiselerinin halledildiği bu nedenle halkın suhulet içerisinde tutulması gerekliliği bildirilmektedir (BOA, MKT, MHM 468/83, 1290).

Devlet Ankara dolaylarında baş gösteren kıtlıkta halkın ihtiyaçlarını gidermek için civar vilayetlerden zahire nakliyesi yapılmasına karar vermiştir. Özellikle Yozgat'ta baş gösteren hadiseler nedeniyle burada nakliye zor olsa da, yine de Yozgat başta olmak üzere İzmit ve Sivas’tan Ankara’ya zahire nakli yapılması Maliye Bakanlığına gönderilen bir tezkire ile istenmektedir (BOA, MKT, MHM 469/30, 1290). 
Kuraklık nedeniyle güçleşen yaşam şartları, kuraklık sahası içerisinde yer alan halkın, kitleler halinde ve düzensiz bir şekilde göç etmeye başlamasına da neden olmuştur. Kıtlık ortamının neden olduğu açlık ve gıda yetersizliği gibi yaşamı güçleştiren unsurların, ilk önce köyleri etkilediği ve kırsal kesimde bulunan insanları, şehir ve kasaba merkezlerine doğru göç etmeye mecbur bıraktığı belirlenmiştir. Göç eden halkın, gittikleri yerlerdeki sınırlı gıda ortamını tüketerek açlığın yayılma alanını arttıracağı ve güvenliği zedeleyeceği endişesiyle hükümetin, kuraklık sahasındaki göçü tasvip etmediği anlaşılmaktadır (Erler 2012: 176). Bu durumu 1304 (1886) tarihli gönderilen bir telgrafnameden anlaşılmaktadır. Bu telgrafnamede Adana, Konya ve Ankara vilayetlerindeki kuraklık ve kitlık dolayısıyla mevcut durum sorgulanmakta gerekli tedbirlerin alınması tembih edilmekte ve vilayetlerle yapılan haberleşme ile göçün engellenmesi hususları üzerinde durulmaktadır (BOA, DH.MKT 1432/56, 1304).

Kitlık sonucu yaşanan göçler ilk önce şehirlerin köylerinden ya da kasabalarından mevcut şehir merkezlerine doğru yapılmaktaydı. Ankara'da, Yozgat'ta, Çorum'da, Konya'da, Adana'da halk büyük ümitlerle taşradan şehir merkezlerine doğru yoğun göçler gerçekleştirmekteydiler. Ancak bu göçler hem göç eden kişilere beklediği yararı sağlayamıyor hem de mevcut merkezlerdeki ahaliyi de olumsuz etkiliyordu. Özellikle Ankara yöresinde kırsal alanlardan şehir ve kasaba merkezlerine yönelik göçler neticesinde umduğunu bulamayan halk, bu defa civar vilayetlere, buralarda da umduğunu bulamayanlar İstanbul'a doğru göç etmeye başlamıştır. Kuraklık sahasından kıtlık nedeniyle kaçanlar, bir dizi sorunu da beraberlerinde taşıdılar. Güvenliğin zedelenmesi, tahıl kıtlığının diğer piyasalarda belirginleşmesi, salgın hastalıklar ve en önemlisi de devletin vatandaşlarına sahip çıkamaması nedeniyle kamuoyu nezdinde saygınlığını yitirmesi gibi problemler bu suretle ortaya çıkmıştır (Erler 2012: 176).

Kamuoyu nezdinde saygınlığını yitirmek istemeyen devlet ise özellikle İstanbul'a doğru yapılan göçleri engellemek için büyük çaba harcamaktaydı. Bu durum 1304 yılında gönderilen bir telgrafta şu şekilde vurgulanmaktadır. Bu telgrafta kıtlık sebebiyle İstanbul'a gitmek üzere Ankara'dan yola çıkan ve İzmit'e gelen üç yüz kadar kişinin burada misafir edilmesi iskân ve iaşelerinin sağlanması aynı şekilde 
Hüdavendigar ve Kastamonu dolaylarına gidenlerin de bu şekilde ağırlanması ve bunların dahi İstanbul'a gitmelerine izin verilmemesi istenmektedir (BOA, DH.MKT 1433/104, 1304).

Kıtlıktan etkilenen yerlerden birinin de Kırşehir olduğu arşiv belgelerinden anlaşılmaktadır. Kırşehir sancağı ve karyelerinde baş gösteren kıtlık ve buna bağlı olarak ortaya çıkan zahire yetersizliği üzerine Maliye Nezareti Celilesine başlıklı bir telgrafta kıtlık sebebiyle zor durumda kalan Kırşehir'in ihtiyacının giderilmesi için Yozgat ambarlarında bulunan zahirenin bir miktarının gönderilmesi istenmektedir (BOA, MKT, MHM 471/76, 1290).

Kıtlık afeti ortaya çıktı̆̆ı yerlerde özellikle yaşlılar ve çocuklar üzerinde daha fazla etkisini hissettirmekteydi bu durumda devletin bir nevi imece yöntemine başvurarak ihtiyaçların zenginler ve belediyelerce giderilmesi yolunu seçmesine neden olmaktadır. Bu durumun izahı ile ilgili 1304 tarihli bir telgrafta kıtlık çeken ve yardım talebinde bulunan bölgeler ahalisinden çocuk ve yaşliların belediye ve zenginlerce ihtiyaçlarının karşılanması; çalışabilecek durumda olanların Göynük, Akçaşehir ve Bartın şose inşaatı amele-i mükellefiyesinde, ekonomik açıdan belli bir seviyenin üzerinde bulunanlardan muafiyet karşılığı alınacak yevmiyelerle çalıştırılması hususunda görüş istenmektedir (BOA, DH.MKT 1436/38, 1304).

Ankara vilayetinden göç eden şahıslardan Tokat yöresinde de barındırılanların olduğu hususu tespit edilerek hükümete bildirilmiştir. Konya vilayetine bağlı bulunan Mandıra, Göstenkil, Aktaş, Öyük, Palazkilikapu'dan halkın, yardım alamadığı ve gönderilen hükümet yardımına da mahallin ileri gelenleri tarafından el konulduğu için göç etmek zorunda kaldıkları bildirilmiştir. Ayrıca Kuraklık sahasından göçerek, İstanbul, Adana, Hüdavendigar, Sivas, Erzurum vilayetleri ile Canik ve İzmit sancaklarında ve diğer bölgelerde bulunan vatandaşların, 20-30.000 civarında olduğunu tespit etmek mümkün olmuştu (Erler 2012: 181).

İstanbul'da Ankara yöresinden kuraklık nedeniyle şehre gelenlerin olduğu, bunun engellenmesi için yerel idareden gerekli tedbirlerin alması istenmekte, ayrıca 
kıtlık nedeniyle İstanbul'a gelenlerin sayımı yapılmaktaydı. Bu sayım sonucu bu rakamın 2.000 kişiye ulaştığı tespit edilmiştir. Anlaşıldığı kadarıyla İstanbul gıda problemini çözemeyen insanların son ümit kapısıydı. Ama İstanbul göçmenlerini gıda sıkıntısının yanında yeni sıkıntılarda beklemekteydi. Bu sıkıntıların başında ise barınma ihtiyacı gelmekteydi. Hükümetin göçmenler için tahsis ettiği açı cezaevi bölgesinin yanında göçmenler Yeni Cami'de mermer merdivenler ile harabe binalarda kalmaktaydı. Göçmen halkın salgın hastalık taşıması endişesinden yerel halk bu göçmenleri evlerine almakta tereddüt etmekte idi (Erler 2012: 180).

Köylerden ve Kasabalardan vilayet merkezlerine toplanma genel eğilimiyle beraber, kent merkezinde yokluğu, yoksulluğu, açlı̆̆ı ve kıtlığı dayanılmaz bir noktaya taşıyordu. Binlerce insan kıtlıktan kaçmak amacıyla (İstanbul'a kadar) uzak yerlere göç etti. Anadolu'da gittikleri yerlere salgın hastalıkları ve umutsuzlukları taşıyorlar, zahire stokları kişi başı hesaplandığı için bu yerlerde de kıtlığa neden oluyorlardı. Örneğin Adana'ya gitmek için Tarsus'tan geçenler Tarsus'u viraneye çevirdi; Tarsus halkı yaylalara kaçtı (Bayer 2013: 54).

Devlet bir taraftan göçü engellemeye çalışıyor bir taraftan da göç eden kişilerin istihdamı konusunda yeni olanaklar araştırıyordu. 1304 (1886) tarihinde sadarete gönderilen bir telgrafta, kıtlık sebebiyle Ankara'dan İstanbul'a gelen ve yevmiye ile yol yapımında çalıştırılmak üzere İzmit'e iadeleri istenen göçmenlerin sayısının aileleri ile birlikte yüz seksen kişiyi buldukları ancak bunların içerisinde çalışabilecek durumda olanların sayısının sadece altmış sekiz olduğu belirtilmekte ve bu kişilerinin ailelerinin doyurulması, ihtiyaçlarının giderilmesi hususu, gerekirse bunların İzmit'e iadesi hususunda İstanbul'dan görüş istenmektedir (BOA, DH.MKT 1433/115, 1304).

İç Anadolu bölgesinde yaşanan bu kıtlıkta gıda ve zahire ihtiyacının karşılanmasında büyük yük iki vilayetin üzerinde idi. Bu vilayetler Konya ve Adana'dır. $\mathrm{Bu}$ vilayetlere zahire talebinin fazla olması nedeniyle devlet buradan alımları yasaklamış daha sonra da bir kararla bu yasaktan vazgeçmiştir. Bu durumla ilgili arşiv kaynaklarında Yaver-i Ekrem hazreti padişahi devletlü Derviş Paşa hazretlerine başlıklı yazıda dile getirilerek; Konya ve Adana vilayetlerinden başka yerlere zahire ithaline 
uygulanan yasağın kaldırıldığı ve durumun gazetelerde ilan edilmesi isteği yer almaktadır (BOA, DH.MKT 1518/73, 1305).

$\mathrm{Bu}$ duruma buğday fiyatlarında yaşanan fiyat artışlarının sebep olduğu da kaçınılmaz bir gerçektir. Arşiv kaynakları incelendiğinde devletin aşırı fiyat artışlarını kontrol altına almak için yukarıda söylediğimiz tedbirin yanında farklı tedbirler aldığı tüccarlarla fiyat pazarlığına girdiğini görmekteyiz. 1303 (1885) y1lında Dahiliye Nezaretine başlıklı bir telgrafta Ankara sancağındaki kıtlık sebebi ile Buğday fiyatlarının artması üzerine Ankara valisinin riyasetinde buğday tüccarları ile yapılan antlaşma sonucu buğday fiyatlarının altı kuruşa kadar indirildiği ve tedabir-i müessireye devam edilmesi istenmektedir (BOA, DH.ŞFR 133/2, 1303).

Kıtlığın biraz hafiflemesi üzerine göç edenlerin geri gönderilmesi meselesi ortaya çıkmıştır. Bu doğrultuda Ankara sancağından İstanbul'a göç edenlerin geri iadelerinin sağlanması ve tutuklu bulunanlarında iadeleri sırasında gerekli tedbirin alınmasına özellikle dikkat edilmiştir (BOA, DH.MKT 1515/61, 1305). Kuraklık sahalarından göç eden halkın, memleketlerine iadeleri esnasında da bazı zorluklarla karşılaşılmıştır. Kıtlık etkisini tam olarak yitirmediğinden geri göç ettirilenlerin yeniden göçe başlaması tehlikesi bulunmaktaydı. Bun- durumun en güzel örneği Ankara'da yaşanmaktaydı. Keskin Kazası ve Karaburun Köyü ahalisi gıda sıkıntısı yaşamaya devam ettikleri için yeniden göçe kalkışmışlardır. Bunun üzerine devlet bazı tedabir almak zorunda kalmış öncelikle bu ahaliye çift hayvanı ve hububat tedarik edilmeye çalışılmıştır (BOA, DH.MKT 1515/61, 1305).

Göçmenlerin iadeleri için gerekli mevsim şartları oluştuğunda yeni bir problemin baş gösterdiği tespit edilmiştir. Göçmenlerin iadesini üstlenen askeri birliklerin ve göçmenlerin yolculuk boyunca tüketecekleri gıda malzemelerinin masraflarının karşılanması güçlüğü, yerel idarelerin de yardımıyla çözülmeye çalışılmıştır. Sadece İplikhane de bulunan göçmenlerin iadesi için harcanan nakliyat masrafının miktarı 8.835 kuruşa ulaşmıştır (BOA, DH.MKT 1515/61, 1305). 
Göçmenler için bedava yolculuk imkânı, beraberinde bazı yolsuzluk olaylarına da zemin hazırlamıştır. Örneğin İnebolu kazasına bağlı Hoşalay Köy'ünden olup İstanbul'da bulunan Fatma Hatun adlı bir kadın, kuraklık nedeniyle İstanbul'a göç ettiğini ve İnebolu iskelesine kadar bedava nakledilmesini talep etmiş ancak yapilan tahkikat neticesinde şahsın, yanlış beyanda bulunduğu tespit edilmiştir (Erler 2012: 188).

\section{Sonuç}

19. Yüzyılda Osmanlı Devleti’nde meydana gelen kıtlık ülke genelinde büyük sıkıntı meydana getirmiştir. Bu sıkıntının İç Anadolu için etkisi de büyük olmuştur. Kıtlık sonucu gıda sıkıntısı yaşayan halk yerlerini, topraklarını terk ederek bir bilinmezin peşinden gitmiştir. Umut için çıktıkları bu yolculuklarda umduklarını bulamamışlardır. Hem göç ederken hem de devletin tedbirleri ile geri döndürülürken büyük sıkıntılar yaşamışlardır. Geçmişimizde yaşanan bu sıkıntılar günümüzde yaşanan aynı hadiseler için birer örnek teşkil etmektedir. Geçmişi iyi anlamak ve analiz etmek bugün yaşanan ve ya yaşanma ihtimali olan benzer olaylar için tedbir almayı kolaylaştıracaktır. Ülkemiz içinde bulunduğu coğrafi konumun etkisini her dönem hissedecektir. Tarihimizde yaşadığımız bu iç göç olayları günümüzde de devam etmektedir ve devam edecektir. Bizlere düşen bugün yaşanan olayların çözümüne odaklanmak ve geçmişte yaşanan acıların benzerlerinin yaşanmasının önüne geçmektir. 


\section{KAYNAKÇA}

\section{Arşiv Kaynakları}

BOA, MKT.MHM, 463/81-466/62, 468/83, 469/30, 471/76, 12908/

BOA, DH.MKT, 1432/56, 1433/104, 1433/115，1434/6, 1436/38，1515/61, $1518 / 73,1533 / 67$

BOA, DH. ŞFR, 133/2, 1303

\section{Araştırma Eserleri}

BAYAR, Yener (2013). 1873-1875 Orta Anadolu Kıtlı̆̆ , Marmara Üniversitesi, Türkiyat Araştırmaları Enstitüsü, Yüksek Lisans Tezi, İstanbul.

ERLER, Mehmet Yavuz (2012). Osmanl Devleti'nde Kuraklık ve Kitlık Olaylarl, İstanbul: Libra Yayınevi.

GÜL, Abdülkadir (2009). “Osmanlı Devleti’nde Kuraklık ve Kitlık Erzurum Örneği”, Sosyal Araştırmalar Dergisi, 2(9): 145-158. Yayınları.

GÜNDÜZ, Tufan (ed.) (2012). Osmanlı Tarihi El Kitabl, Ankara: Grafiker

OĞUZ, Ahmet (2016). “19. Yüzyılın Son Çeyreğinde Yozgat’ta Açlık Kıtlık ve Zahire Ticareti”, I. Uluslararası Bozok Sempozyumu, ss. 530-537.

TEKIN, Saadet (2015). “19. Yüzyılın Sonu 20. Yüzyılın Başlarında Batı Anadolu'da Yaşanan Kuraklık Olayları”, International Journal of Social Science, 33: 329-341.

UZUNÇARŞILI, İ. Hakkı (1998). Osmanlı Tarihi, I, Ankara: Türk Tarih Kurumu Yayınları. 
Meriç AYBAR, "Osmanlı Devletinde Kıtlık ve İç Göç: 1870-1900 Arası İç Anadolu Örneği”, Mavi Atlas, 5(2)/2017: 474-488.

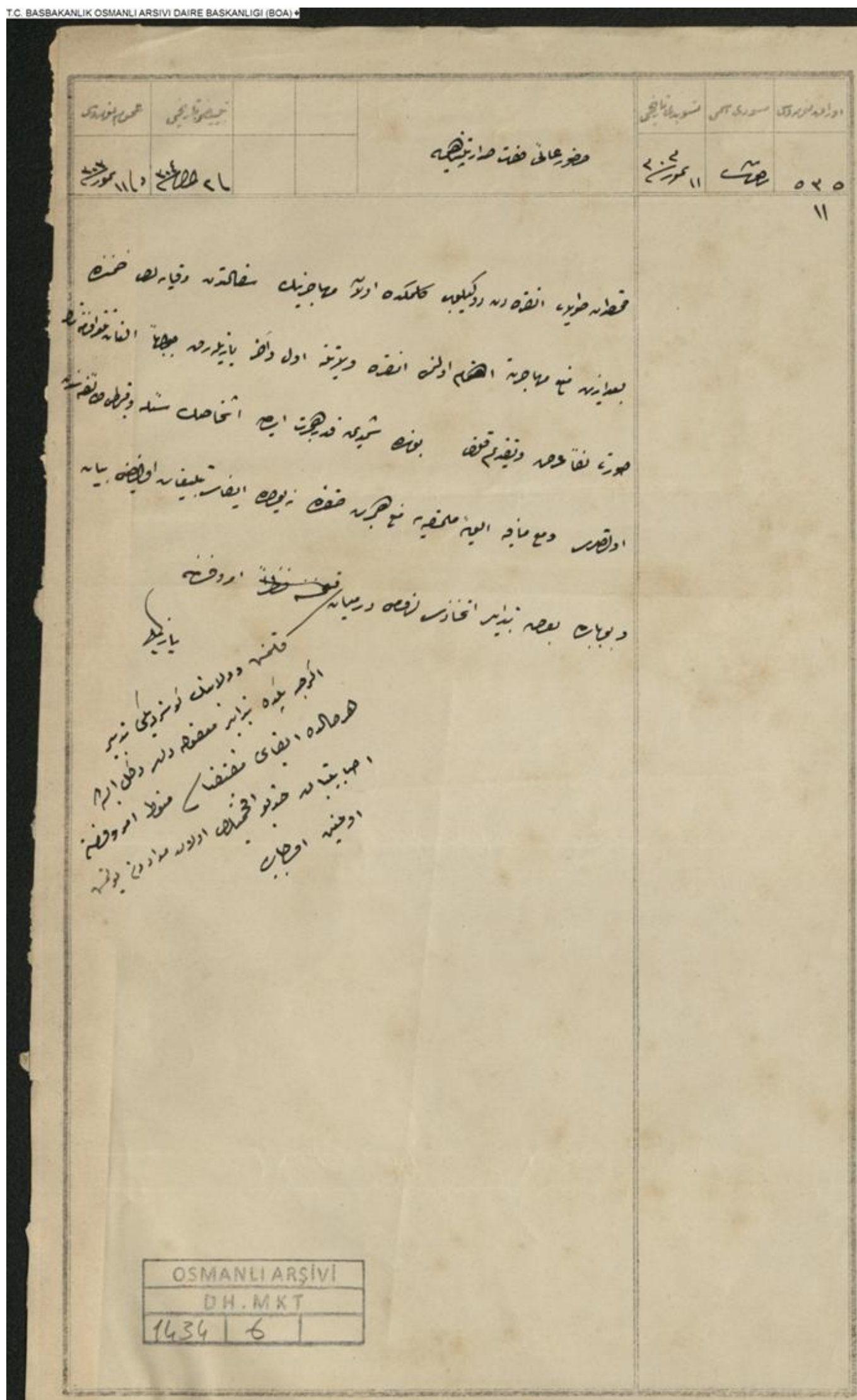


Meriç AYBAR, “Osmanlı Devletinde Kıtlık ve İç Göç: 1870-1900 Arası İç Anadolu Örneği”, Mavi Atlas, 5(2)/2017: 474-488.

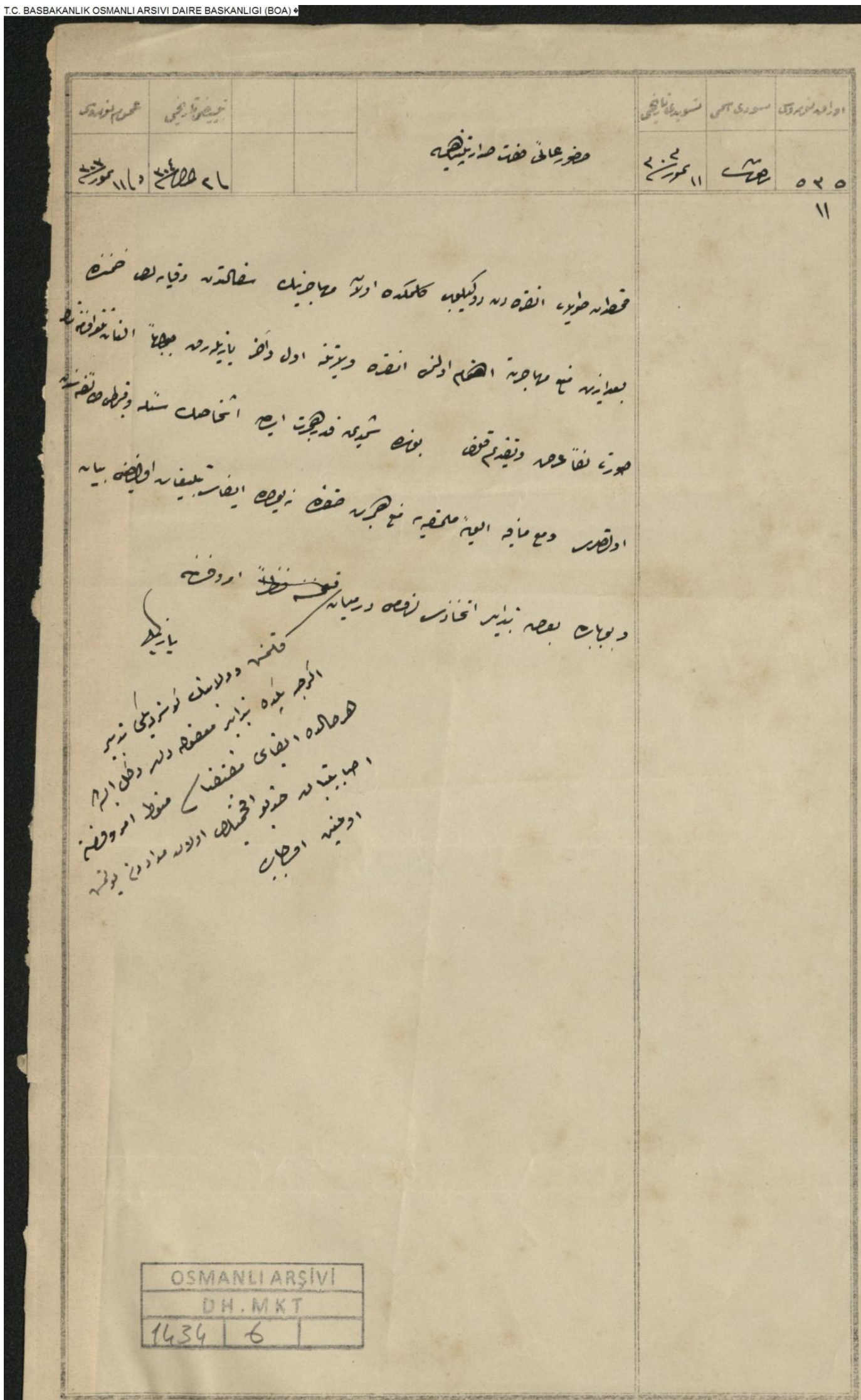


Meriç AYBAR, “Osmanlı Devletinde Kıtlık ve İç Göç: 1870-1900 Arası İç Anadolu Örneği””, Mavi Atlas, 5(2)/2017: 474-488.

C. BASBAKANLIK OSMANLIARSIVI DAIRE BASKANLIGI (BOA)

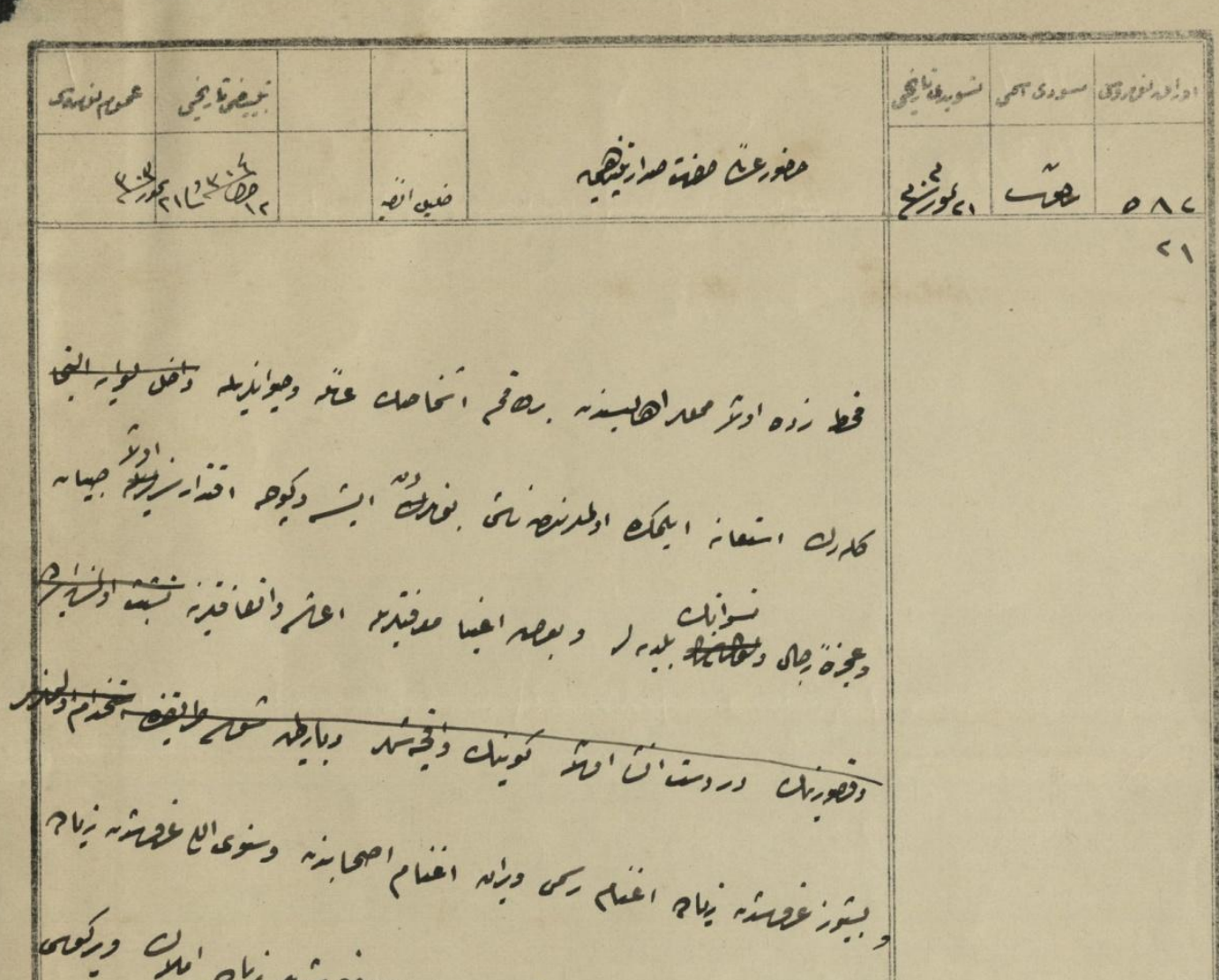

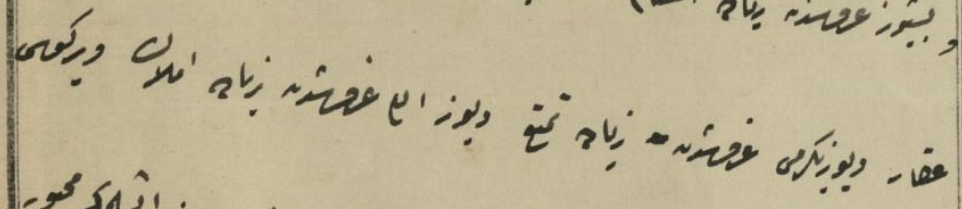

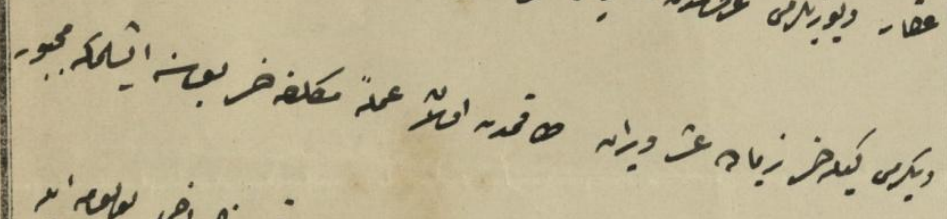

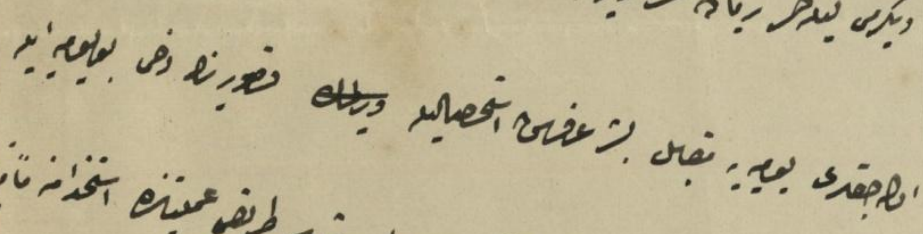

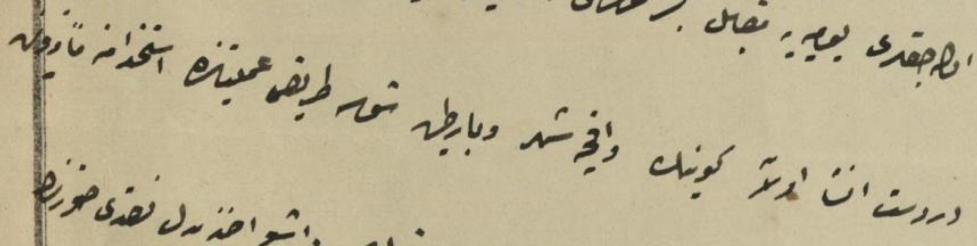

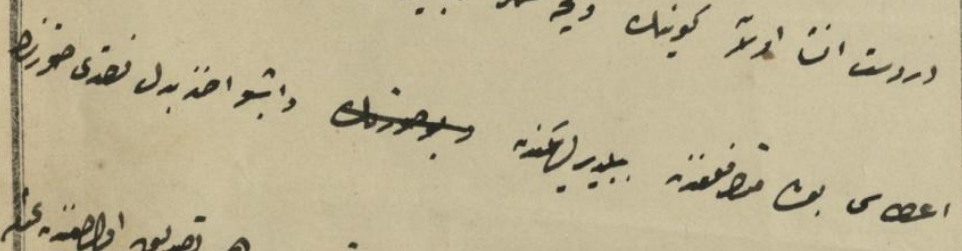

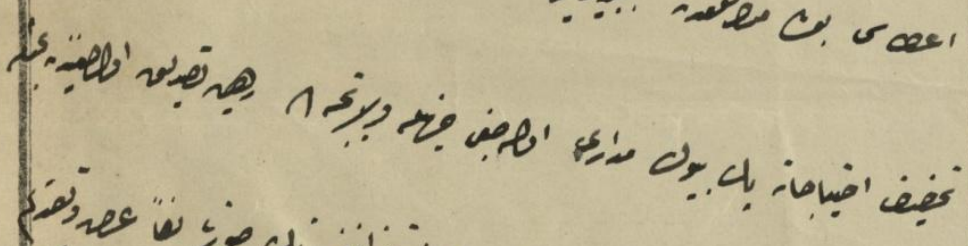

إِى ".

2 irt

نمنى

DH.MKT.01436.00038.001 
Meriç AYBAR, “Osmanlı Devletinde Kıtlık ve İç Göç: 1870-1900 Arası İç Anadolu Örneği”, Mavi Atlas, 5(2)/2017: 474-488.

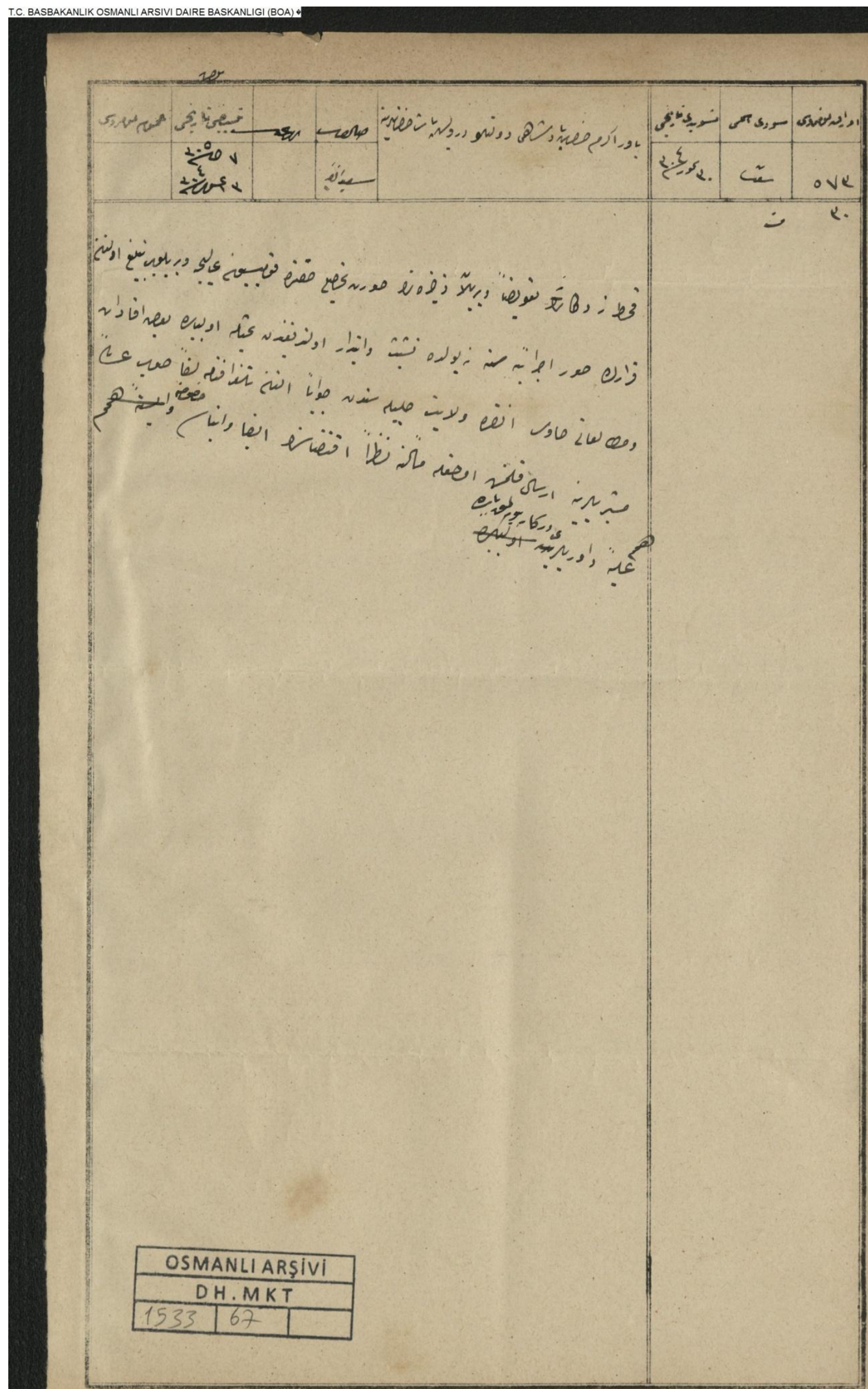


Meriç AYBAR, "Osmanlı Devletinde Kıtlık ve İç Göç: 1870-1900 Arası İç Anadolu Örneği”, Mavi Atlas, 5(2)/2017: 474-488.

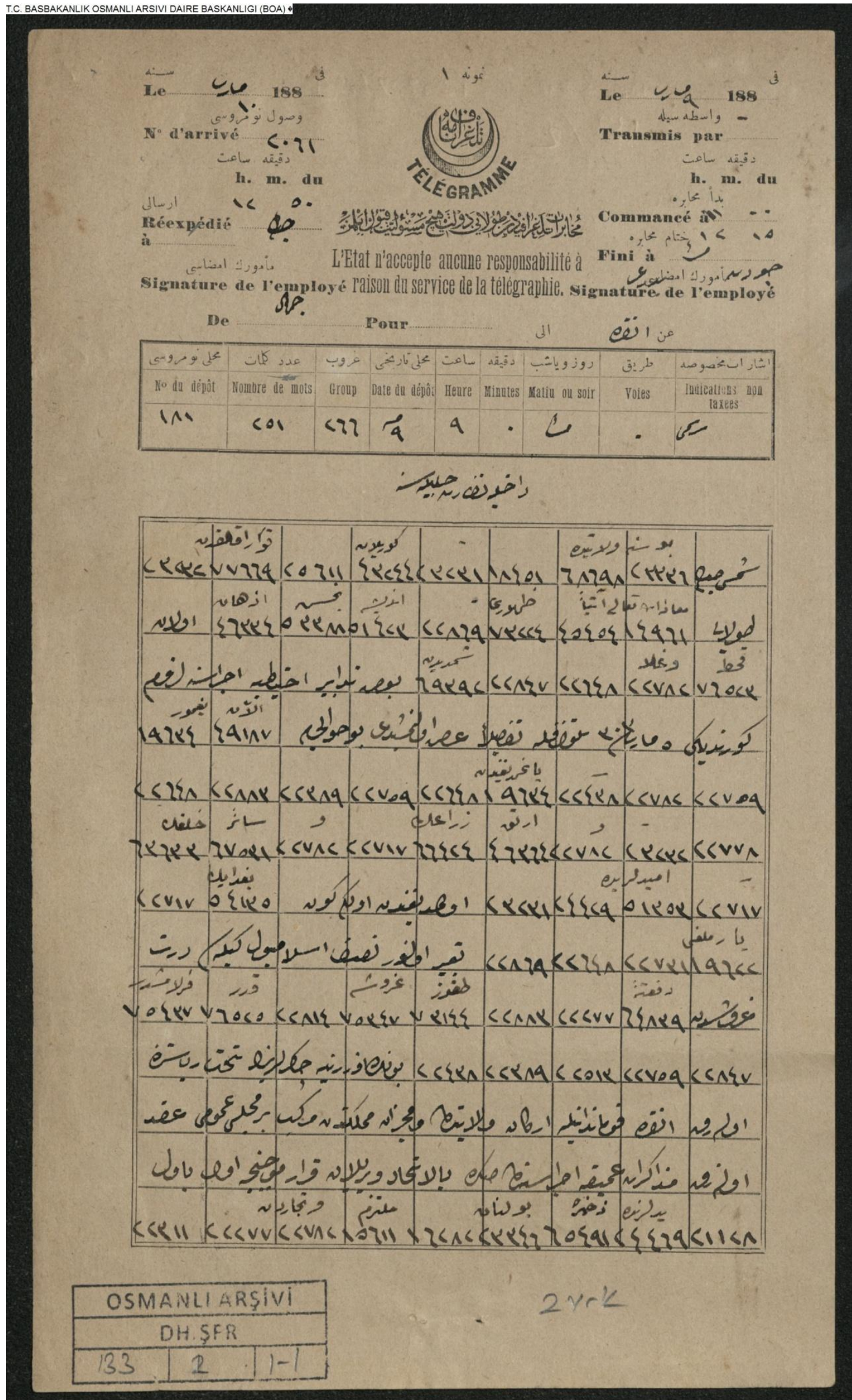

